\title{
In Vitro Propagation of Three Species of Columnar Cacti from the Sonoran Desert
}

\author{
Eugenio Pérez-Molphe-Balch ${ }^{1}$, Martha Evelia Pérez-Reyes, \\ Carlos Antonio Dávila-Figueroa, and Enrique Villalobos-Amador \\ Dpto. de Química. Universidad Autónoma de Aguascalientes Av. Universidad \\ 94020100 Aguascalientes, Ags. México
}

Additional index words. areole activation, cactaceae, Carnegiea gigantea, cytokinin,
Pachycereus pringlei, Stenocereus thurberi, tissue culture

\begin{abstract}
In vitro propagation systems were developed for Carnegiea gigantea (Engelm.) Britt \& Rose, Pachycereus pringlei (Berger) Britt \& Rose and Stenocereus thurberi (Engelm.) Buxb, three North American species of columnar cacti. In vitro germinated seedlings were used as a source of explants. Multiple shoot formation from areoles was achieved for three types of explants (apical, lateral, and transverse) cultured on Murashige and Skoog (MS) basal media supplemented with $3 \%$ sucrose, $10 \mathrm{~g} \cdot \mathrm{L}^{-1}$ agar and various treatments with growth regulators. The highest shoot production efficiency for $C$. gigantea was obtained on transverse explants cultured on a medium with $2 \mathrm{mg} \cdot \mu_{\mathrm{ML}} \mathrm{L}^{-1}(8.87 \mu \mathrm{M}) \mathrm{BA}$, where 5.3 shoots per explant were obtained. In $P$. pringlei and $S$. thurberi the best response was obtained using transverse explants on medium with $1 \mathrm{mg} \cdot \mathrm{L}^{-1}(4.44 \mu \mathrm{M}) \mathrm{BA}(3.8$ and 4.3 shoots per explant, respectively). Rooting of the in vitro generated shoots was achieved most efficiently on MS basal media with $3 \%$ sucrose, $10 \mathrm{~g} \cdot \mathrm{L}^{-1}$ agar and $1 \mathrm{mg} \cdot \mathrm{L}^{-1}(4.9 \mu \mathrm{M})$ indole-3-butyric acid. Rooting frequencies were $92 \%, 88 \%$, and $96 \%$ for $C$. gigantea, $P$. pringlei and $S$. thurberi, respectively, and the frequency of survival of the plants once transferred to soil was $86 \%$ on average. Chemical name used: benzyladenine (BA).
\end{abstract}

The most distinctive feature in the landscape of the Sonoran Desert in North America is the presence of giant columnar cacti. Among the most important of these species are Carnegiea gigantea, Pachycereus pringlei, and Stenocereus thurberi. Carnegiea gigantea, known as 'Sahuaro' or 'Saguaro', is large, columnar, and slightly ramified, with stems that reach up to $12 \mathrm{~m}$ in height. This species is distributed in the northern part of the Sonora state in Mexico and in the southern parts of Arizona and California in the United States. Pachycereus pringlei are gigantic plants with chandelier-like ramifications, that measure up to $15 \mathrm{~m}$ high. This species is distributed in the Mexican states of Baja California and Sonora. S. thurberi, called 'Pitayo dulce', is a highly ramified species without a well-defined main trunk that can reach $7 \mathrm{~m}$ in height. This species is found in the states of Baja California, Sonora and Sinaloa in México and in Arizona in the U.S. (Bravo-Hollis and Sánchez-Mejorada, 1978). These three species all produce edible fruits, of which the best known are those of $S$. thurberi which are called "pitaya." Mizrahi et al. (1997) includes these three in a list of 34 cactus species with horticultural potential as fruit and industrial crops. As is common for many of the cactus species in México, natural

Received for publication 8 Mar. 2001. Accepted for publication 11 Oct. 2001. We express our sincere thanks to Roberto Rico Martinez and Nora Lilia Vasco Mendez for the critical reading of this manuscript. This work was supported by the Universidad Autónoma de Aguascalientes, México (PIB-97-4). ${ }^{1}$ To whom reprint requests should be addressed. populations of these species have decreased steadily. This is due mainly to the destruction of habitats because of land use for agriculture or livestock, overcollection of young wild plants for sale, and several phytopathological problems. This situation is more serious due to the extremely slow growth and poor recovery capacity of wild populations of cacti, which is due to the inefficiency of their natural multiplication by seed (Ault and Blackmon, 1987). Cactus seedlings are susceptible to predation and damping off, and require protection from nurse plants that provide shade for successful establishment (Bravo-Hollis and SánchezMejorada, 1978). These facts confirm the importance to search for alternatives to make their multiplication more efficient and to accelerate the initial rate of growth of new plantlets of these species.

In vitro culture and micropropagation offer useful alternatives for the multiplication and conservation of cactus species. These techniques have the potential to produce many plants in a short time in minimal space and their success has already been demonstrated for several cacti species. However, each species responds differently to the conditions established for in vitro multiplication, rooting and acclimatization, making it necessary to optimize these culture conditions for each cactus species that would be micropropagated (Hubstenberger et al., 1992). An additional advantage of micropropagation is that in vitro development of cactus plantlets can be extremely rapid in comparison with ex vitro cultured seedlings (Ault and Blackmon, 1987; George, 1996). Malda et al. (1999a) showed that in vitro cultured plants of Coryphantha minima grew 7-fold larger than plants cultured under similar ex vitro conditions. This may be due to high humidity, plant growth regulators, and high sugar concentration in the culture media.

In vitro propagation of Mexican species of cacti has been demonstrated for Mammillaria san-angelensis (Martínez-Vázquez and Rubluo, 1989), M. candida (Elias-Rocha et al., 1998), Obregonia denegrii and Coryphantha minima (Malda et al., 1999b). In a previous study, Pérez-Molphe-Balch et al. (1998) developed systems for micropropagation of 21 species of Mexican cacti belonging to the genera Astrophytum, Cephalocereus, Coryphantha, Echinocactus, Echinocereus, Ferocactus, Mammillaria, Nyctocereus, and Stenocactus. In this work, we describe methods for in vitro propagation of three columnar species: $C$. gigantea, $P$. pringlei and $S$. thurberi. These methods could become valuable for the conservation and commercial production of these species.

\section{Materials and Methods}

Plant material. In vitro germinated seedlings of Carnegiea gigantea, Pachycereus pringlei and Stenocereus thurberi were used as tissue sources. The fruits of the three taxa were collected from mature wild plants that grew in Ejido Quitoback, near Sonoita, in Sonora, México, in Aug. 1997. Seeds were washed eight times with $0.1 \%$ Extran (Merck) in water to eliminate the remains of the fruit pulp, then disinfected for $1 \mathrm{~min}$ in $70 \%$ ethanol, $25 \mathrm{~min}$ in $2 \%$ sodium hypochlorite, and rinsed four times with sterile distilled water. Seeds were germinated in culture vessels containing half-strength Murashige and Skoog (MS) basal medium (Murashige and Skoog, 1962). All culture media were adjusted to $5.7 \mathrm{pH}$ with $\mathrm{NaOH}$ before addition of $8 \mathrm{~g} \cdot \mathrm{L}^{-1}$ agar (Sigma Chemical Co., St. Louis). The culture jars (baby food jars) with $30 \mathrm{~mL}$ of culture medium each were sterilized in an autoclave at $120{ }^{\circ} \mathrm{C}$ for $15 \mathrm{~min}$. Eight to ten seeds were planted per culture jar. All cultures were incubated at $25 \pm 2{ }^{\circ} \mathrm{C}$ on a 16 $\mathrm{h}$ light/8-h dark cycle under fluorescent light (54 $\mu \mathrm{mol} \cdot \mathrm{m}^{-2} \cdot \mathrm{s}^{-1}$, day light lamps).

Shoot proliferation. The $20-25 \mathrm{~mm}$ plantlets (120 to 150 day old) obtained from the in vitro germinated seeds were used as sources of explants for the proliferation experiments. This proliferation was carried out by means of axillary bud activation. Three different explant types were tested: apical explants, lateral explants (shoots without apex cut longitudinally), and transverse segments $\approx 4 \mathrm{~mm}$ wide (shoots without apex cut transversely). The explants were placed into culture jars (baby food jars) containing $30 \mathrm{~mL}$ MS basal media (Murashige and Skoog, 1962) with $3 \%$ sucrose, $10 \mathrm{~g} \cdot \mathrm{L}^{-1}$ agar and one of eight treatments with plant growth regulators (Tables 1-3), then capped with polypropylene caps. These treatments were selected for their effectiveness with other cactus species (PérezMolphe-Balch et al., 1998) and results of preliminary experiments with these same species 
Table 1. Shoot production by three types of explant (apical, lateral, or transverse) of Carnegiea gigantea on eight growth regulator treatments.

\begin{tabular}{|c|c|c|c|c|c|}
\hline \multicolumn{3}{|c|}{ Growth regulators $\mathrm{mg} \cdot \mathrm{L}^{-1}(\mu \mathrm{M})$} & \multicolumn{3}{|c|}{ Shoots per explant ${ }^{2}$} \\
\hline BA & $2 \mathrm{iP}$ & NAA & Apical & Lateral & Transverse \\
\hline $1(4.4)$ & & & $4.5 \pm 0.5 \mathrm{a}$ & $3.3 \pm 0.3 \mathrm{a}$ & $4.0 \pm 0.4 \mathrm{ab}$ \\
\hline $2(8.8)$ & & & $2.9 \pm 0.4 \mathrm{bc}$ & $3.9 \pm 0.4 \mathrm{a}$ & $5.3 \pm 0.5 \mathrm{a}$ \\
\hline $2(8.8)$ & & $0.5(2.7)$ & $2.4 \pm 0.3 \mathrm{bcd}$ & $2.3 \pm 0.3 a b c$ & $3.0 \pm 0.4 \mathrm{bc}$ \\
\hline $3(13.3)$ & & & $2.6 \pm 0.3 b c$ & $3.0 \pm 0.4 \mathrm{ab}$ & $2.9 \pm 0.3 b c$ \\
\hline & $1(4.9)$ & & $1.6 \pm 0.2 \mathrm{~cd}$ & $0.9 \pm 0.1 \mathrm{c}$ & $1.6 \pm 0.3 \mathrm{c}$ \\
\hline & $2(9.8)$ & & $3.3 \pm 0.4 \mathrm{ab}$ & $2.4 \pm 0.3 \mathrm{abc}$ & $2.9 \pm 0.5 \mathrm{bc}$ \\
\hline & $2(9.8)$ & $0.5(2.7)$ & $1.2 \pm 0.1 \mathrm{~d}$ & $1.7 \pm 0.2 \mathrm{bc}$ & $2.0 \pm 0.4 \mathrm{c}$ \\
\hline & $3(14.8)$ & & $2.6 \pm 0.3 b c$ & $2.7 \pm 0.3 \mathrm{ab}$ & $3.7 \pm 0.3 \mathrm{ab}$ \\
\hline
\end{tabular}

${ }^{2}$ Values represent means \pm SE of 25-40 explants of each type per treatment. Data pooled from three independent experiments. Means followed by the same letter in each column do not significantly differ at $5 \%$ level by Tukey-Kramer multiple comparisons test.

Table 2. Shoot production by three types of explant (apical, lateral, or transverse) of Pachycereus pringlei on eight growth regulator treatments.

\begin{tabular}{|c|c|c|c|c|c|}
\hline \multicolumn{3}{|c|}{ Growth regulators $\mathrm{mg} \cdot \mathrm{L}^{-1}(\mu \mathrm{M})$} & \multicolumn{3}{|c|}{ Shoots per explant ${ }^{2}$} \\
\hline BA & $2 \mathrm{iP}$ & NAA & Apical & Lateral & Transversal \\
\hline $1(4.4)$ & & & $1.7 \pm 0.2 \mathrm{abc}$ & $3.3 \pm 0.4 \mathrm{a}$ & $3.8 \pm 0.3 \mathrm{a}$ \\
\hline $2(8.8)$ & & & $1.5 \pm 0.2 \mathrm{abc}$ & $2.7 \pm 0.3 \mathrm{ab}$ & $2.9 \pm 0.3 \mathrm{ab}$ \\
\hline $2(8.8)$ & $0.5(2.7)$ & & $2.3 \pm 0.2 \mathrm{a}$ & $1.5 \pm 0.2 \mathrm{bc}$ & $1.3 \pm 0.3 \mathrm{de}$ \\
\hline $3(13.3)$ & & & $1.6 \pm 0.2 \mathrm{abc}$ & $2.5 \pm 0.3 \mathrm{ab}$ & $2.4 \pm 0.2 \mathrm{bc}$ \\
\hline & $1(4.9)$ & & $1.2 \pm 0.1 \mathrm{c}$ & $0.9 \pm 0.1 \mathrm{c}$ & $1.2 \pm 0.1 \mathrm{de}$ \\
\hline & $2(9.8)$ & & $1.6 \pm 0.2 \mathrm{abc}$ & $2.1 \pm 0.4 \mathrm{abc}$ & $1.6 \pm 0.2 \mathrm{~cd}$ \\
\hline & $2(9.8)$ & $0.5(2.7)$ & $2.0 \pm 0.2 \mathrm{ab}$ & $1.0 \pm 0.2 \mathrm{c}$ & $0.6 \pm 0.1 \mathrm{e}$ \\
\hline & $3(14.8)$ & & $1.4 \pm 0.2 \mathrm{bc}$ & $2.9 \pm 0.3 \mathrm{a}$ & $2.8 \pm 0.3 \mathrm{ab}$ \\
\hline
\end{tabular}

${ }^{2}$ Values representmeans \pm SE of 25-40 explants of each type per treatment. Data pooled from three independent experiments. Means followed by the same letter in each column do not significantly differ at $5 \%$ level by Tukey-Kramer multiple comparisons test.

Table 3. Shoot production by three types of explant (apical, lateral, or transverse) of Stenocereus thurberi on eight growth regulator treatments.

\begin{tabular}{|c|c|c|c|c|c|}
\hline \multicolumn{3}{|c|}{ Growth regulators $\mathrm{mg} \cdot \mathrm{L}^{-1}(\mu \mathrm{M})$} & \multicolumn{3}{|c|}{ Shoots per explant ${ }^{2}$} \\
\hline $\mathrm{BA}$ & $2 \mathrm{iP}$ & NAA & Apical & Lateral & Transversal \\
\hline $1(4.4)$ & & & $2.3 \pm 0.2 \mathrm{ab}$ & $3.7 \pm 0.3 \mathrm{a}$ & $4.3 \pm 0.4 \mathrm{a}$ \\
\hline $2(8.8)$ & & & $2.8 \pm 0.3 \mathrm{a}$ & $3.4 \pm 0.4 \mathrm{ab}$ & $2.6 \pm 0.3 b$ \\
\hline $2(8.8)$ & & $0.5(2.7)$ & $1.6 \pm 0.3 b c$ & $1.7 \pm 0.3 \mathrm{c}$ & $1.1 \pm 0.2 \mathrm{~cd}$ \\
\hline $3(13.3)$ & & & $1.5 \pm 0.2 b c$ & $2.1 \pm 0.3 \mathrm{c}$ & $2.3 \pm 0.3 b c$ \\
\hline & $1(4.9)$ & & $1.4 \pm 0.1 \mathrm{c}$ & $1.2 \pm 0.2 \mathrm{c}$ & $1.4 \pm 0.2 \mathrm{bcd}$ \\
\hline & $2(9.8)$ & & $1.7 \pm 0.1 b c$ & $1.5 \pm 0.2 \mathrm{c}$ & $2.1 \pm 0.2 b c$ \\
\hline & $2(9.8)$ & $0.5(2.7)$ & $1.7 \pm 0.2 \mathrm{bc}$ & $1.4 \pm 0.3 \mathrm{c}$ & $0.7 \pm 0.1 \mathrm{~d}$ \\
\hline & $3(14.8)$ & & $2.3 \pm 0.3 \mathrm{ab}$ & $2.3 \pm 0.3 b c$ & $2.3 \pm 0.4 b c$ \\
\hline
\end{tabular}

${ }^{2}$ Values represent means \pm SE of 25-40 explants of each type per treatment. Data pooled from three independent experiments. Means followed by the same letter in each column do not significantly differ at $5 \%$ level by Tukey-Kramer multiple comparisons test.

(data not shown). We used 25-40 explants of each type per treatment. These experiments were conducted at three independent times for each species. The number of shoots produced from each explant was recorded after 12 weeks of incubation. A completely random experimental design was used. Data were analyzed through analysis of variance (ANOVA) and means were separated by Tukey-Kramer mul- tiple range test at the 5\% level. In most of the cultures, primary explant segments with shoots were subcultured onto fresh shoot induction medium for continuous proliferation, until the shoots $(>12 \mathrm{~mm})$ in some cultures were collected for rooting experiments.

Rooting. Shoots (12-20 mm) were transferred for rooting to MS basal medium with $3 \%$ sucrose, $10 \mathrm{~g} \cdot \mathrm{L}^{-1}$ agar and one of six rooting treatments (Table 4). For these experiments, 25 shoots were used per treatment and experiments were conducted at two different times for each species. Results were recorded after 5 weeks. Rooting was considered positive if shoots exhibited roots $\geq 10 \mathrm{~mm}$. The rooted plants were transplanted to pots containing a mix of 1 ground sand : 1 soil and covered with plastic bags for 2-3 weeks to prevent desiccation and to allow acclimatization. Additionally, another group of in vitro generated shoots (25 of each species) were rooted ex vitro. For this, their basal ends were impregnated with a commercial rooting mix (Raizone, San Luis Potosí, México) and shoots were cultivated under the above described conditions. In both cases, survival percentages were determined 16 weeks after transplantation.

\section{Results and Discussion}

Explants of all three species exhibited shoot production from the areoles after 12 weeks of incubation in all growth regulators treatments tested. Over the range of concentrations used, BA had a greater effect than $2 \mathrm{iP}$ for the activation of axillary buds. The highest proliferation rate was reached with $\mathrm{BA}$ using shoot transverse segments as explants (Tables 1-3). In these cases, 5.3 shoots per explant in $C$. gigantea, 3.8 shoots per explant in $P$. pringle $i$ and 4.3 shoots per explant in $S$. thurberi were obtained. The production of shoots from apical and lateral explants was lower. Considering that each plantlet or in vitro generated shoot produces at least three explants (one apical and two or more transverse), this means that after 12 weeks $15.1,9.8$, and 11.3 new shoots can be expected from a single seedling of $C$. gigantea, $P$. pringlei, and $S$. thurberi, respectively. In the case of the lateral and transverse explants, all shoots produced were homogeneous in size and differentiation stage (Fig. 1a-d). When apical explants were used, a dominant shoot of greater size and small side shoots were produced. The dominant shoot derived by the elongation of the apex, and the small shoots occurred at its base. Although we did not find previous reports on micropropagation of these species, their proliferation rates (shoots per explant) were similar to those reported for other cacti like Coryphantha clavata (4.7), C. durangensis (4.4), C. radians (4.1), Echinocereus dubius (4.9), and E. pectinatus (3.9) (Pérez-Molphe-Balch et al., 1998).

Table 4. Rooting and acclimatization of in vitro generated shoots of Carnegiea gigantea, Pachycereus pringlei, and Stenocereus thurberi receiving one of six treatments to encourage rooting.

\begin{tabular}{|c|c|c|c|c|c|c|}
\hline \multirow[b]{2}{*}{$\begin{array}{l}\text { In vitro } \\
\text { rooting treatment }\end{array}$} & \multicolumn{2}{|c|}{ Carnegiea gigantea } & \multicolumn{2}{|c|}{ Pachycereus pringlei } & \multicolumn{2}{|c|}{ Stenocereus thurberi } \\
\hline & $\begin{array}{c}\text { Rooting } \\
\text { frequency }(\%)^{\mathrm{z}}\end{array}$ & $\begin{array}{c}\text { Survival } \\
\text { ex vitro }(\%)\end{array}$ & $\begin{array}{c}\text { Rooting } \\
\text { frequency }(\%)^{\mathrm{z}}\end{array}$ & $\begin{array}{c}\text { Survival } \\
\text { ex vitro }(\%)\end{array}$ & $\begin{array}{c}\text { Rooting } \\
\text { frequency }(\%)^{\mathrm{z}}\end{array}$ & $\begin{array}{c}\text { Survival } \\
\text { ex vitro }(\%)\end{array}$ \\
\hline Basal medium & 48 & 83 & 56 & 93 & 64 & 75 \\
\hline $2 \mathrm{~g} \cdot \mathrm{L}^{-1} \mathrm{AC}^{\mathrm{y}}$ & 60 & 87 & 68 & 76 & 68 & 94 \\
\hline $1.0 \mathrm{mg} \cdot \mathrm{L}^{-1}(5.7 \mu \mathrm{M}) \mathrm{IAA}$ & 56 & 86 & 72 & 83 & 80 & 85 \\
\hline $2 \mathrm{~g} \cdot \mathrm{L}^{-1} \mathrm{AC}+1.0 \mathrm{mg} \cdot \mathrm{L}^{-1}(5.7 \mu \mathrm{M}) \mathrm{IAA}$ & 60 & 73 & 76 & 89 & 72 & 78 \\
\hline $1.0 \mathrm{mg} \cdot \mathrm{L}^{-1}(4.9 \mu \mathrm{M}) \mathrm{IBA}$ & 92 & 91 & 88 & 95 & 96 & 92 \\
\hline $2 \mathrm{~g} \cdot \mathrm{L}^{-1} \mathrm{AC}+1.0 \mathrm{mg} \cdot \mathrm{L}^{-1}(4.9 \mu \mathrm{M}) \mathrm{IBA}$ & 88 & 91 & 86 & 87 & 84 & 90 \\
\hline
\end{tabular}

${ }^{2}$ Values represent rooting frequencies of 50 shoots per treatment. Data pooled from two independent experiments.

${ }^{y}$ Activated charcoal. 
Microshoots of all three species reported in this work originated from the axillary buds in the areoles. This is desirable because micropropagated cacti regenerated from axillary buds are considered to be genetically stable (Machado and Prioli, 1996; Vyskot and Jara, 1984). When the cultures were kept for $>14$ weeks on media containing cytokinins with subculture at $\approx 12$ weeks, secondary proliferation occurred (new shoots formed from areoles of the primary shoots). This process maintains the cultures in continuous proliferation indefinitely.

In treatments containing NAA, moderate growth of pale green calli was observed in less than $15 \%$ of the explants. Although shoot regeneration from calli has been demonstrated in cacti (de Oliveira et al., 1995; Wakhlu and Bhau, 2000), this is undesirable for clonal propagation because it favors somaclonal variation (Lee and Phillips, 1988). Production of callus in the columnar species reported in this work was lower than that found in other genera of globular cacti such as Mammillaria and Coryphantha (Pérez-Molphe-Balch et al., 1998). In some cases, we observed a slight browning due to oxidation of phenolic compounds in the areas of the explants where the cut was done, but this did not affect shoot production. Hyperhydration or vitrification of tissues is a serious problem for in vitro culture of cacti (Elias-Rocha et al., 1998). Although hyperhydration did not reduce the number of shoots produced, it may impede their rooting and survival ex vitro. This physiological disorder is due to conditions of in vitro culture, i.e., high humidity, excess carbohydrates and minerals, high levels of plant growth regulators, and low light intensity (Ziv, 1991). In this work, hyperhydration was only observed in some Stenocereus thurberi shoots (Fig. 1d). Hyperhydration may have been controlled by the use of high concentrations of agar $\left(10 \mathrm{~g} \cdot \mathrm{L}^{-1}\right)$ to diminish water availability in the medium, and by lowering concentration of plant growth regulators. These conditions have been shown to reduce hyperhydration in other cactus tissue cultures (Elias-Rocha et al., 1998; Pérez-Molphe-Balch et al., 1998).

In the three species examined, rooting was achieved on all media tested. However, higher frequencies were obtained with $1 \mathrm{mg} \cdot \mathrm{L}^{-1} \mathrm{IBA}$. $S$. thurberi had the highest rooting frequency followed by $C$. gigantea and $P$. pringle $i$ with $96 \%, 92 \%$, and $88 \%$, respectively (Table 4). The in vitro generated roots were vigorous (Fig. 2 ) and the frequency of survival of the plants once transferred to soil was $86 \%$ on average (Table 4). Regarding rooting of differentiated shoots treated ex vitro with commercial rooting mixture, we observed rooting rates of $36 \%$, $32 \%$, and $40 \%$ in C. gigantea, $P$. pringlei, and $S$. thurberi, respectively. Hence, for these conditions, in vitro rooting was more efficient for these species.

This work describes protocols for in vitro mass propagation of three species of North American columnar cacti. These species have an ecological and ornamental value in desert landscapes and some economic potential due to their fruits that are appreciated locally. The
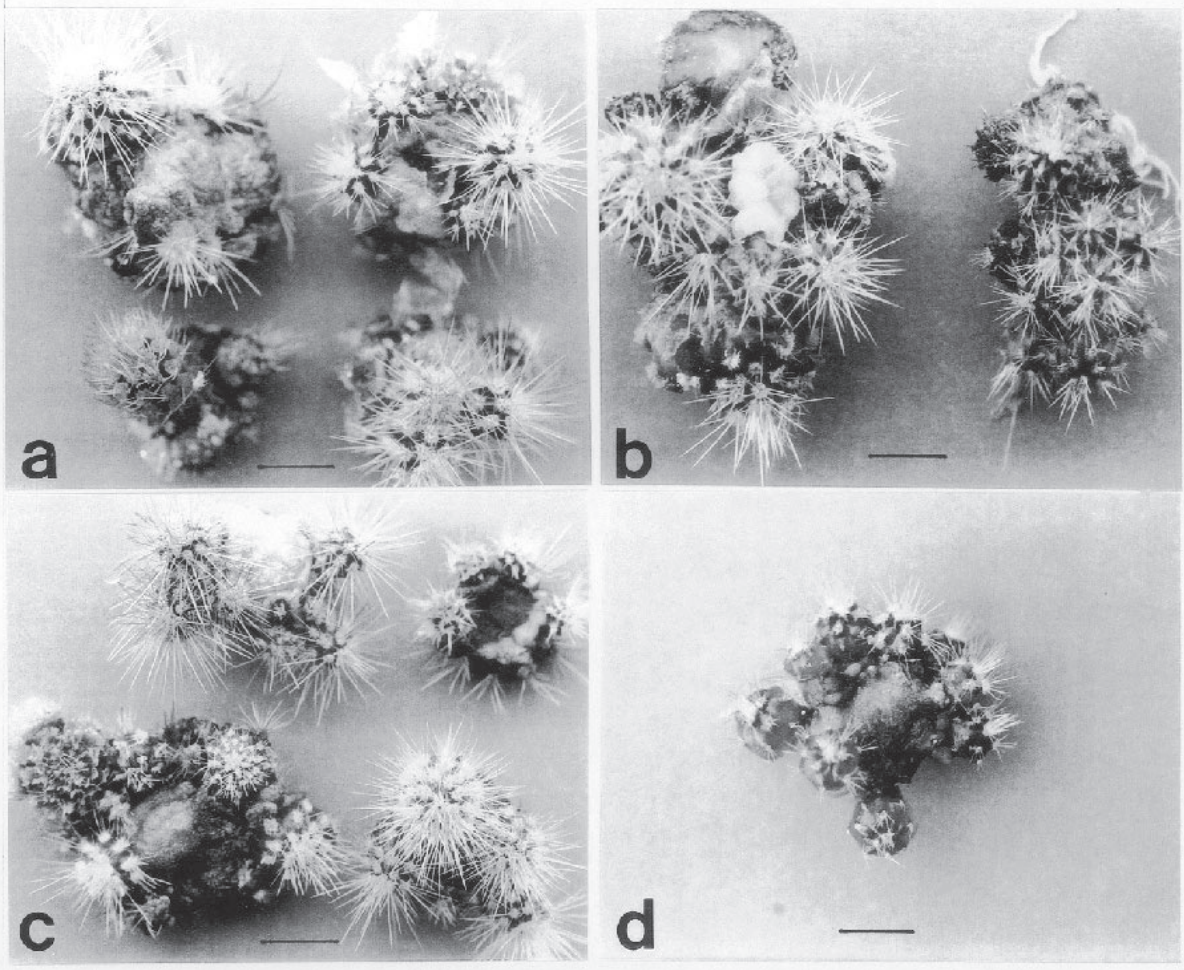

Fig. 1. In vitro shoot proliferation in C. gigantea, P. pringlei, and S. thurberi after 12 weeks of culture using (a) transverse explants of $C$. gigantea with $2 \mathrm{mg} \cdot \mathrm{L}^{-1} \mathrm{BA}$, (b) lateral explants of $C$. gigantea with $2 \mathrm{mg} \cdot \mathrm{L}^{-1} \mathrm{BA}$, (c) transverse explants of $P$. pringlei with $1 \mathrm{mg} \cdot \mathrm{L}^{-1} \mathrm{BA}$, and (d) transverse explants of S. thurberi with $1 \mathrm{mg} \cdot \mathrm{L}^{-1} \mathrm{BA}$. Note hyperhydration in some of the shoots on the left in $\mathrm{d}(\mathrm{bar}=1 \mathrm{~cm})$.
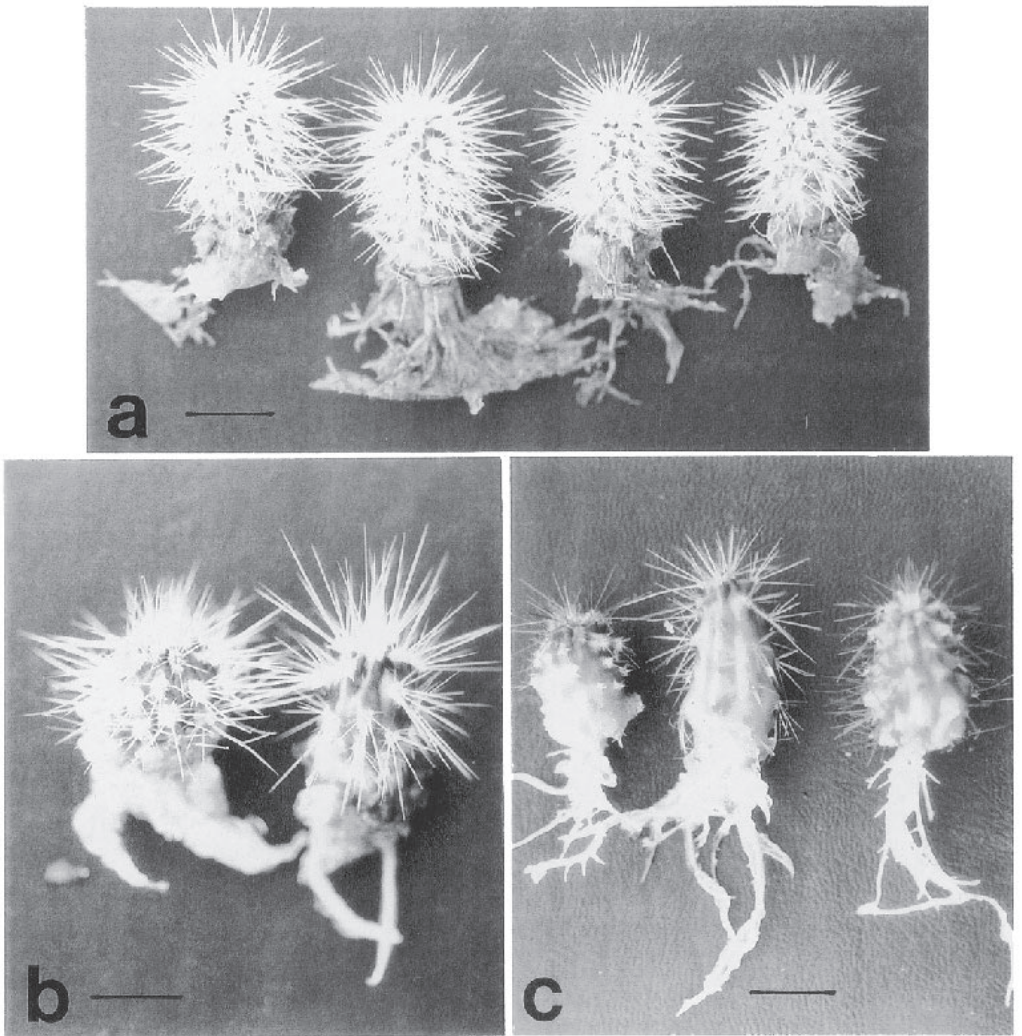

Fig. 2. Rooting of in vitro produced shoots of (a) C. gigantea, (b) P. pringlei, and (c) S. thurberi. Roots were generated on media with $1 \mathrm{mg} \cdot \mathrm{L}^{-1}$ IBA after 5 weeks $($ bar $=1 \mathrm{~cm}$ ). 
micropropagation systems are considerably more effective than traditional methods of propagation and can be valuable for conservation, commercial production or for repopulation of damaged natural areas.

\section{Literature Cited}

Ault, J.R. and W.J. Blackmon. 1987. In vitro propagation of Ferocactus acanthodes (Cactaceae). HortScience 22:126-127

Bravo-Hollis, H. and H. Sánchez-Mejorada. 1978. Las Cactáceas de México. Vol. I. Universidad Nacional Autónoma de México, México

de Oliveira, S.A., M.F.P.S. Machado, A.J. Prioli, and C.A Mangolin. 1995. In vitro propagation of Cereus peruvianus Mill. (Cactaceae). In Vitro Cell. Dev. Biol.-Plant 31:47-50

Elias-Rocha M.A., M.S. Sántos-Díaz, and A. Arredondo-Gómez. 1998. Propagation of Mammillaria candida (Cactaceae) by tissue culture techniques. Haseltonia 6:96-101

George, E.F. 1996. Plant propagation by tissue culture. Part 2. $2^{\text {nd }}$ ed. Exegetics Ltd. Edington, U.K.
Hubstenberger, J.F., P.W.Clayton, and G.C. Phillips. 1992. Micropropagation of cacti (Cactaceae), p. 49-68. In: Y.P.S. Bajaj (ed.). Biotechnology in agriculture and forestry, Vol. 20. High-tech and micropropagation IV. Springer-Verlag, Berlin

Lee, M. and R.L. Phillips. 1988. The chromosomal basis of somaclonal variation. Ann. Rev. Plant Physiol. Mol. Biol. 39:413-437

Machado, M.F.P.S. and A.J. Prioli. 1996. Micropropagation of Cereus peruvianus Mill. (Cactaceae) by areole activation. In Vitro Cell. Dev. Biol.-Plant 32:199-203

Malda, G., R.A. Backhaus, and C. Martin. 1999a. Alterations in growth and crassulacean acid metabolism (CAM) activity of in vitro cultured cactus. Plant Cell Tiss. Org. Cult. 58:1-9.

Malda, G., H. Suzan, and R.A. Backhaus. 1999b. In vitro culture as a potential method for the conservation of endangered plants possessing crassulacean acid metabolism. Sci. Hort. 81:71-87

Martínez-Vázquez, O. and A. Rubluo. 1989. In vitro mass propagation of the near-extinct Mammillaria san-angelensis Sánchez-Mejorada. J. Hort. Sci. 64:99-105
Mizrahi, Y., A. Nerd, and P.S. Nobel. 1997. Cacti as crops. Hort. Rev. 18:291-320

Murashige, T. and F. Skoog. 1962. A revised medium for rapid growth and bioassays with tobacco tissue cultures. Physiol. Plant. 15:473497

Pérez-Molphe-Balch, E., M.E. Pérez-Reyes, E. Villalobos-Amador, E. Meza-Rangel, L.R. Morones-Ruiz, and H. Lizalde-Viramontes. 1998. Micropropagation of 21 species of Mexican cacti by axillary proliferation. In Vitro Cell. Dev. Biol.-Plant 34:131-135

Vyskot, B. and Z. Jara. 1984. Clonal propagation of cacti through axillary buds in vitro. J. Hort. Sci. 59:449-452

Wakhlu, A.K. and B.S. Bhau. 2000. Callus formation and plant regeneration from tubercles of Coryphantha elephantidens (Lem.) Lem. In Vitro Cell. Dev. Biol.-Plant 36:211-214

Ziv, M.1991. Vitrification: morphological and physiological disorders of in vitro plants. p. 45-69. In: P.C. Debergh and R.H. Zimmerman (eds.). Micropropagation. technology and application. Kluwer Academic, Dordrecht. 